\title{
PURCHASE INTENTION: PENGARUH PRICE DISCOUNT, BONUS PACK DAN CELEBRITY ENDORSER
}

\author{
Adithya Melano Zetira, Meilaty Finthariasari ${ }^{1}$ \\ Jurusan Manajemen, Fakultas Ekonomi dan Bisnis, Universitas Muhammadiyah \\ Bengkulu \\ adithyamelano@gmail.com,mheyfinta@umb.ac.id ${ }^{1 \ltimes}$
}

\begin{abstract}
ABSTRAK
Penelitian ini bertujuan untuk mengetahui pengaruh diskon harga, paket bonus, dan celebrity endorser terhadap niat beli online shop Moy Stuff di Kota Bengkulu. Sampel penelitian ini adalah 180 orang Konsumen online shop Moy Stuff di Kota Bengkulu. Penelitian ini menggunakan observasi dan angket sebagai teknik pengumpulan data. Teknik analisis data yang digunakan dalam penelitian ini antara lain dengan menggunakan uji instrumen, uji asumsi klasik, analisis responden, analisis regresi linier berganda, koefisien determinan, dan pengujian hipotesis. Hasil pengujian menunjukkan bahwa variabel diskon harga (X1), paket bonus (X2), celebrity endorser (X3) berpengaruh simultan terhadap niat beli online shop Moy Stuff di kota Bengkulu. Dari hasil uji regresi linier berganda diperoleh persamaan regresi adalah $\mathrm{Y}=0,521+0,294(\mathrm{X} 1)+0,135(\mathrm{X} 2)+0,459(\mathrm{X} 3)$.
\end{abstract}

Kata kunci: Diskon Harga, Paket Bonus, Endorser Selebriti, Purchase Initention

\begin{abstract}
This study aimed to determine the effect of price discount, bonus pack, and celebrity endorser toward purchase intention of Moy Stuff online Shop in Bengkulu City. The sample of this research was 180 people of Moy Stuff online shop Consumers in Bengkulu City. This study used observation and questionnaires as techniques for collecting data. Several data analysis techniques were used in this research, including using instrument test, classical assumption test, respondent analysis, multiple linear regression analysis, determinant coefficient, and hypothesis testing. The results of the tests show that the variable price discount (X1), bonus pack (X2), celebrity endorser (X3) have a simultaneous effect on purchase intention on Moy Stuff online shop in Bengkulu city. From the results of the multiple linear regression test, the regression equation is $\mathrm{Y}=0.521+0.294(\mathrm{X} 1)+0.135(\mathrm{X} 2)$ $+0.459(\mathrm{X} 3)$.
\end{abstract}

Keywords: Price Discount, Bonus Pack, Celebrity Endorser, Purchase Intention

\footnotetext{
${ }^{1} \rtimes$ Corresponding author: Meilaty Finthariasari (mheyfinta@umb.ac.id)
} 


\section{PENDAHULUAN}

Price discount dan bonus pack merupakan promosi penjualan yang paling banyak digunakan, baik penjualan online maupun offline (Chen et al., 2012). Mishra \& Mishra, (2011) berpendapat bahwa price discount merupakan strategi promosi penjualan berbasis harga di mana pelanggan ditawarkan produk yang sama dengan harga yang berkurang, sedangkan bonus pack merupakan strategi promosi penjualan berbasis kuantitas di mana pelanggan ditawarkan produk dengan kuantitas yang lebih dengan harga yang sama.

Periklanan pada dasarnya adalah alat yang digunakan dalam proses pemberian informasi kepada khalayak sehingga akan terjadi komunikasi persuasif didalamnya (Kotler \& Keller, 2009). Periklanan memiliki tiga pokok tujuan didalamnya, yaitu sebagai pemberi informasi, membujuk para konsumen, dan mengingatkan produk yang di iklankan kepada calon konsumen. Salah satu elemen iklan yang dapat meningkatkan nilai penjualan produk adalah celebrity endorser yang akan dapat membantu membuat hubungan emosional yang lebih kuat dengan konsumen (Shimp, 2003).

Moy Stuff adalah online store yang bergerak secara online dan offline. Di Kota Bengkulu, Moy Stuff adalah satu-satunya toko yang menggunakan jasa celebrity endorser dalam aktivitas penjualan produknya. Moy Stuff menjual berbagai macam keperluan wanita seperti baju, celana, sepatu, skincare dan accesories. Moy Stuff memiliki media promosi online berupa instagram dan Shopee, Moy Stuff juga memiliki offline store yang berlokasi di Jl. Danau. Panorama. Kec. Singaran Pati. Kota Bengkulu. Sesuai dengan judul penelitian ini Moy Stuff akan dijadikan objek survey secara online maupun terjun langsung kelapangan untuk mengukur Pengaruh price discount, bonus pack dan celebrity endrose terhadap purchase intention.

Jasa celebrity endorser yang pernah digunakan oleh toko Moy, yaitu Anya Geraldin dan Awkarin. Anya Geraldin adalah seorang selebgram yang mempunyai followers sebanyak 4,4 jt Followers di instagram, Anya Geraldin dikenal sebagai sosok yang fashionable dikalangan anak muda. Sedangkan Awkarin adalah seorang selebrgam sekaligus musisi yang mempunyai followers 5,4 jt followers, Awkarin memiliki dampak yang besar terhadap kalangan anak muda untuk meniru gaya fashionnya.

Dari data pengunjung yang di peroleh dari Insight Instagram Moy Stuff, menunjukkan perminggunya pengunjung toko online shop Moy Stuff dikunjungi calon konsumen sebanyak 14.461 orang dan perharinya mengalami kenaikan dan penurunan calon konsumen yang mengunjungi online shop Moy Stuff. Calon konsumen yang paling banyak mengujungi online shop Moy Stuff terdapat di hari senin dan jum'at sedangkan pada hari lain nya menagalami penurunan. Dari data tersebut menunjukkan bahwa pengunjung mengalami ketidakstabilan setiap harinya. Sehingga dalam hal ini menjadi temuan pertama peneliti untuk mengangkat permasalaha celebrity endorser untuk menganalisis keputusan pembelian konsumen toko Moy Stuff. Kemudian hal kedua dan ketiga terkait dengan fenomena gap penelitian yang peneliti temui adalah apakah price dan bonus pack yang ditawarkan toko Moy Stuff saat ini dapat menarik konsumen untuk membeli produk setelah adanya pengaruh dari variable celebrity endorser.

\section{KAJIAN LITERATUR Purchase Initention}

Purchase intention merupakan kemungkinan konsumen akan melakukan pembelian produk tertentu dan sebagai rencana dari konsumen untuk melakukan upaya dalam membeli. Kesediaan pelanggan untuk membeli memiliki probabilitas yang lebih tinggi, meskipun pelanggan belum tentu benar-benar membelinya. Niat beli ditentukan oleh manfaat dan nilai yang dirasakan oleh konsumen (Wang \& Tsai, 2014). Menurut Annafik dan Rahardjo (2012) 
minat beli merupakan bagian dari komponen perilaku dalam sikap mengkonsumsi. Indikator Purchase intention menurut Schiffman dan Kanuk (2007) dijelaskan oleh beberapa komponen yaitu: 1) tertarik untuk mencari informasi tentang produk, 2) mempertimbangkan untuk membeli, 3) tertarik untuk mencoba, 4) ingin mengetahui produk serta 5) ingin memiliki produk

\section{Price Discount}

Price Discount adalah potongan harga yang bertujuan menarik konsumen, sehingga harga sesungguhnya lebih rendah dari harga umumnya dan discount yang diberikan harus mempunyai arti penting bagi konsumen (Machfoedz, 2005). Menurut Kotler dan Keller (2009) discount adalah harga resmi yang diberikan perusahaan kepada konsumen yang bersifat lunak demi meningkatkan penjualan suatu produk barang atau jasa.

Belch \& Belch (2009) juga mengemukakan ada beberapa indikator yang dapat digunakan untuk mengukur variabel Price Discount yang terdiri dari tiga indikator, yaitu : 1) dapat memicu konsumen untuk membeli dalam jumlah yang banyak, 2) mengantisipasi promosi pesaing, serta 3) mendukung perdagangan dalam jumlah yang lebih besar. Maka hipotesis 1 penelitian ini sebagai berikut:

H1: Price Discount berpengaruh terhadap Purchase intention

\section{Bonus Pack}

Menurut Belch \& Belch (2009) bonus pack menawarkan konsumen sebuah muatan ekstra dari sebuah produk dengan harga normal. Menurut Mishra \& Mishra (2011) bonus pack merupakan strategi promosi penjualan berbasis kuantitas di mana pelanggan ditawarkan produk dengan kuantitas lebih dengan harga yang sama. Shimp (2000) mendefinisikan bonus pack adalah tambahan produk dari perusahaan untuk diberikan kepada konsumen dengan harga yang sama. Menurut Boyd (2002) bonus pack adalah upaya untuk menarik pembelian dengan menawarkan produk atau jasa gratis dengan harga yang sudah dikurangi untuk mendorong pembelian produk lain. Hipotesis kedua penelitian sebagai berikut;

$\mathrm{H} 2$ : bonus pack berpengaruh terhadap Purchase intention

\section{Celebrity Endorser}

Menurut Shimp (2003), endorser adalah pendukung iklan atau yang dikenal juga sebagai bintang iklan untuk mendukung suatu produk. Sedangkan selebriti adalah tokoh (actor, penghibur atau atlet) yang terkenal atau dikenal karena prestasinya dalam bidang bidang yang berbeda dari produk yang di dukungnya (Shimp, 2003). Suryadi (2006) mendefinisikan bahwa endorser adalah ikon atau sering disebut juga sebagai direct source (sumber langsung) untuk mengantarkan sebuah pesan dan atau memperagakan sebuah produk atau jasa dalam kegiatan promosi yang bertujuan untuk mendukung efektifitas penyampaian pesan produk. Hipotesis ketiga penelitian sebagai berikut;

H2: Celebrity Endorser berpengaruh terhadap Purchase intention

\section{METODE PENELITIAN}

Jenis Penelitian ini adalah penelitian pendekatan deskriptif kuantitatif. Populasi dalam penelitian ini adalah konsumen / pelanggan online shop Moy Stuff di kota Bengkulu yang jumlah tidak diketahui (infinite). Ukuran sampel peneliti adalah jumlah indikator dikali 5 sampai 10. Adapun total sampel penelitian sebanyak 180 reponden. Teknik pengumpulan data dengan menggunakan, yang kemudian data diolah dan dianalisis dengan menggunakan alat analisis SPSS. Kerangka penelitian dapat dilihat pada Gambar 1. 


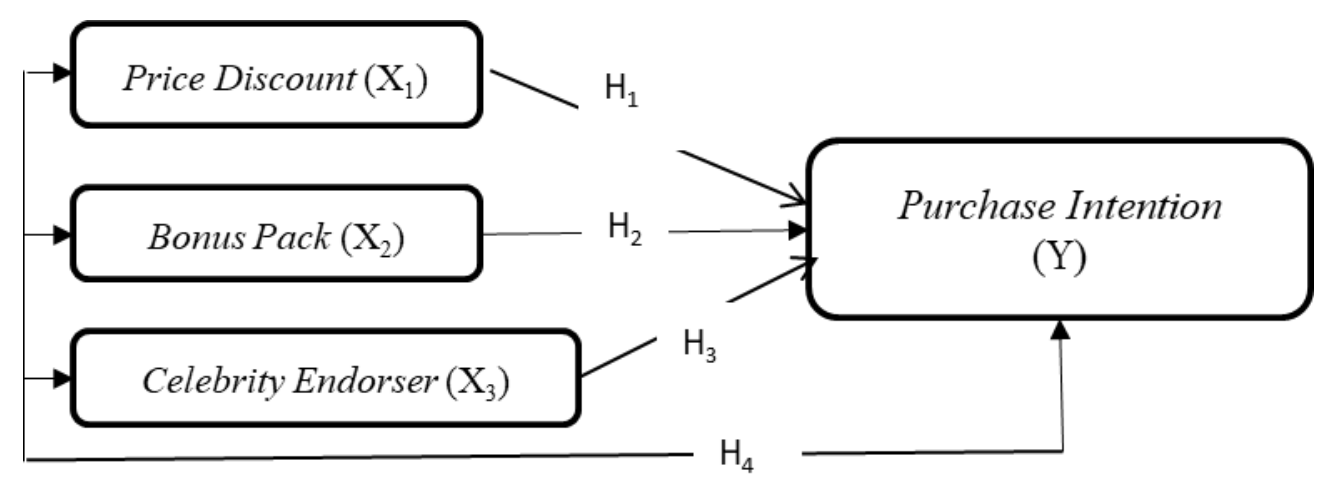

Gambar 1. Kerangka Penelitian

\section{HASIL PENELITIAN DAN PEMBAHASAN}

Berdasarkan Tabel 1 diatas diketahui karakteristik responden berdasarkan jenis kelamin laki-laki sebanyak 25 orang responden atau 13,89\%, kemudian jumlah responden perempuan sebanyak 155 orang responden atau 86,11\%. Dari data tersebut menyatakan bahwa konsumen Moy Stuff lebih banyak perempuan dari pada laki-laki.

Tabel 1. Karakteristik Responden Berdasarkan Jenis Kelamin

\begin{tabular}{|c|c|c|}
\hline Jenis Kelamin & Frekuensi & Persentase \\
\hline Laki-laki & 25 & $13,89 \%$ \\
\hline Perempuan & 155 & $86,11 \%$ \\
\hline Total & 180 & $100 \%$ \\
\hline
\end{tabular}

Berdasarkan Tabel 2 diketahui karakteristik responden berdasarkan usia yang paling mendominasi usia 16-25 sebanyak 125 responden dengan persentase 69,44\%. Dari data tersebut dapat disimpulkan bahwa rata-rata konsumen pada online shop Moy Stuff Kota Bengkulu berada pada kisaran usia 16-25 tahun.

Tabel 2. Karakteristik Responden Berdasarkan Usia

\begin{tabular}{|c|c|c|}
\hline Usia & Frekuensi & Persentase \\
\hline $16-25$ & 125 & $69,44 \%$ \\
\hline $26-35$ & 38 & $21,11 \%$ \\
\hline $36-40$ & 10 & $5,56 \%$ \\
\hline$>40$ & 7 & $3,89 \%$ \\
\hline Total & 180 & $100 \%$ \\
\hline
\end{tabular}

Dari Tabel 3 dapat dilihat bahwa $r \geq 0,30$. Ini menunjukan bahwa item dari setiap pertanyaan koesioner masing-masing variabel tersebut adalah valid dan layak untuk digunakan dalam penelitian ini. Artinya item dari setiap pertanyaan tersebtut mampu mengukur dan menjelaskan variabel secara tepat. 
Tabel 3. Hasil Uji Validitas

\begin{tabular}{|c|c|c|c|c|}
\hline Variabel & Item & R tabel & R hitung & Keterangan \\
\hline \multirow{3}{*}{$\begin{array}{l}\text { Price } \\
(\mathrm{X} 1)\end{array}$} & $\mathrm{X} 1.1$ & 0.30 & 0.726 & Valid \\
\hline & $\mathrm{X} 1.2$ & 0.30 & 0.543 & Valid \\
\hline & $\mathrm{X} 1.3$ & 0.30 & 0.455 & Valid \\
\hline \multirow[b]{3}{*}{ Bonus pack (X2) } & $\mathrm{X} 2.1$ & 0.30 & 0.640 & Valid \\
\hline & $\mathrm{X} 2.2$ & 0.30 & 0.693 & Valid \\
\hline & $\mathrm{X} 2.3$ & 0.30 & 0.653 & Valid \\
\hline \multirow{4}{*}{$\begin{array}{l}\text { Celebrity Endorser } \\
\text { (X3) }\end{array}$} & X3.1 & 0.30 & 0.805 & Valid \\
\hline & $\mathrm{X} 3.2$ & 0.30 & 0.763 & Valid \\
\hline & X3.3 & 0.30 & 0.826 & Valid \\
\hline & $\mathrm{X} 3.4$ & 0.30 & 0.826 & Valid \\
\hline \multirow{5}{*}{$\begin{array}{l}\text { Celebrity Endorser } \\
\text { (X3) }\end{array}$} & $\mathrm{X} 3.5$ & 0.30 & 0.826 & Valid \\
\hline & $\mathrm{X} 3.6$ & 0.30 & 0.679 & Valid \\
\hline & X3.7 & 0.30 & 0.679 & Valid \\
\hline & $\mathrm{X} 3.8$ & 0.30 & 0.805 & Valid \\
\hline & $\mathrm{X} 3.9$ & 0.30 & 0.805 & Valid \\
\hline \multirow{3}{*}{$\begin{array}{l}\text { Purchase intention } \\
\text { (Y) }\end{array}$} & Y1 & 0.30 & 0.887 & Valid \\
\hline & Y2 & 0.30 & 0.753 & Valid \\
\hline & Y3 & 0.30 & 0.490 & Valid \\
\hline
\end{tabular}

Sumber: Output SPSS 24 yang diolah 2021

Tabel 4 menunjukan hasil pengujian terhadap masing-masing variabel, dapat disimpulkan bahwa semua variabel menunjukan sebagai suatu ukuran yang reliabel dengan Cronbach's Alpa lebih dari 0,60. Hal ini berarti instrument penelitian koesioner memiliki hasil yang reliable (konsisten) sehingga instrument ini layak untuk digunakan dalam penelitian.

Tabel 4. Hasil Uji Reliabilitas

\begin{tabular}{|l|c|c|c|}
\hline \multicolumn{1}{|c|}{ Variabel } & Cronbach's Alpha & R tabel & Keterangan \\
\hline Price Discount $(\mathrm{X} 1)$ & 0,6 & 0,724 & Reliabel \\
\hline Bonus pack $(\mathrm{X} 2)$ & 0,6 & 0,809 & Reliabel \\
\hline Celebrity Endorser $(\mathrm{X} 3)$ & 0,6 & 0,943 & Reliabel \\
\hline Purchase intentions $(\mathrm{Y})$ & 0,6 & 0,834 & Reliabel \\
\hline
\end{tabular}

Sumber: Output SPSS 24 yang diolah 2021

Hasil perhitungan regresi linear berganda dengan mengunakan program SPSS 24 for windows maka dapat diperoleh persamaan regresi linear berganda sebagai berikut:

$$
Y=0,521+0,294(X 1)+0,135(X 2)+0,459(X 3)
$$

Persamaan regresi tersebut dapat dijelaskan sebagai berikut (Tabel 5):

1. Nilai konstanta 0,521 mempunyai arti bahwa apabila variabel Price Discount (X1), Bonus pack (X2), Celebrity Endorser (X3) terhadap Purchase intention (Y), sama dengan nol maka variabel Purchase intention akan tetap sebesar 0,521. 
2. Pengaruh Price Discount (X1) terhadap Purchase intentions (Y). Nilai koefisien regresi variabel X1 (Price Discount) adalah 0,294, variabel Price Discount bernilai positif, hal ini menunjukan adanya pengaruh positif atau hubungan searah atara variabel Price Discount (X1) dengan variabel Purchase intention (Y). Artinya apabila nilai Price Discount naik maka akan meningkatkan Purchase intention sebesar 0,294.

3. Pengaruh Bonus pack (X2) terhadap Purchase intention (Y). Nilai koefisien regresi variabel X2 (Bonus pack) adalah 0,135, variabel Bonus pack bernilai positif, hal ini menunjukan adanya pengaruh positif atau hubungan searah atara variabel Bonus pack (X2) dengan variabel Purchase intention (Y). Artinya apabila nilai Bonus pack naik maka akan meningkatkan Purchase intention sebesar 0,135 .

4. Pengaruh Celebrity Endorser (X3) terhadap Purchase intention (Y). Nilai koefisien regresi variabel X3 (Celebrity Endorser) adalah 0,459, variabel Celebrity Endorser bernilai positif, hal ini menunjukan adanya pengaruh positif atau hubungan searah atara variabel Celebrity Endorser (X3) dengan variabel Purchase intention (Y). Artinya apabila nilai Celebrity Endorser naik maka akan meningkatkan Purchase intention sebesar 0,459.

Tabel 5. Hasi Uji Linear Berganda

\begin{tabular}{|c|c|c|c|c|c|c|}
\hline \multicolumn{7}{|c|}{ Coefficients $^{\mathbf{a}}$} \\
\hline \multirow{2}{*}{\multicolumn{2}{|c|}{ Model }} & \multicolumn{2}{|c|}{$\begin{array}{l}\text { Unstandardized } \\
\text { Coefficients }\end{array}$} & \multirow{2}{*}{\begin{tabular}{|l|}
$\begin{array}{l}\text { Standardized } \\
\text { Coefficients }\end{array}$ \\
Beta
\end{tabular}} & \multirow[t]{2}{*}{$\mathrm{t}$} & \multirow[t]{2}{*}{ Sig. } \\
\hline & & $\mathrm{B}$ & Std. Error & & & \\
\hline \multirow[t]{4}{*}{1} & (Constant) & 0,521 & 0,645 & & 0,808 & 0,420 \\
\hline & $\mathrm{X} 1$ & 0,294 & 0,055 & 0,246 & 5.309 & 0,000 \\
\hline & $\mathrm{X} 2$ & 0,135 & 0,053 & 0,141 & 2.565 & 0,011 \\
\hline & $\mathrm{X} 3$ & 0,459 & 0,027 & 1.004 & 16.716 & 0,000 \\
\hline
\end{tabular}

Sumber: Output SPSS 24 yang diolah, 2021

Berdasarkan Tabel 6 diperoleh nilai koefisien korelasi $(\mathrm{R})=0,836$ yang berarti ada hubungan antara variabel independent terhadap varibel dependent. Besar koefisien korelasi 0,836 terletak pada interval 0,80 - 1,000 yang berarti korelasi hubungan antara variabel independent (price discount, bonus pack, celebrity endorser) dengan variabel dependent Purchase intention adalah termasuk sangat kuat.

Tabel 6. Koefisien Korelasi

\begin{tabular}{|l|l|l|l|l|}
\hline \multicolumn{2}{|l|}{ Model Summary } \\
\hline Model & $\mathrm{R}$ & R Square & $\begin{array}{l}\text { Adjusted } \\
\text { Square }\end{array}$ & $\begin{array}{l}\text { Std. Error of } \\
\text { the Estimate }\end{array}$ \\
\hline 1 & $.836^{\mathrm{a}}$ & .699 & .694 & 1.21132 \\
\hline \multicolumn{7}{|l}{ a. Predictors: (Constant), X3, X1, X2 } \\
\hline
\end{tabular}

Sumber: Output SPSS 24 yang diolah, 2021

Dari hasil perhitungan dari SPSS (Tabel 7) dapat diketahui nilai koefisien determinasi dari nilai $\mathrm{R}^{2}$ (R Square) yaitu 0,699. Hal ini berarti bahwa Price Discount (X1), Bonus pack (X2), dan Celebrity Endorser (X3) berpengaruh terhadap Purchase 
intention (Y) sebesar 69,9\% sedangkan sisanya 30,1\% dipengaruhi oleh variabel - variabel lainnya yang tidak di teliti dalam penelitian ini.

Tabel 7. Koefisien Determinasi

\begin{tabular}{|l|l|l|l|l|}
\hline \multicolumn{6}{|l|}{ Model Summary } \\
\hline Model & $\mathrm{R}$ & R Square & $\begin{array}{l}\text { Adjusted R } \\
\text { Square }\end{array}$ & $\begin{array}{l}\text { Std. Error of } \\
\text { the Estimate }\end{array}$ \\
\hline 1 & $.836^{\mathrm{a}}$ & .699 & .694 & 1.21132 \\
\hline \multicolumn{7}{|l|}{ a. Predictors: (Constant), X3, X1, X2 } \\
\hline
\end{tabular}

Sumber: Output SPSS 24 yang diolah, 2021

Berdasarkan hasil uji t (secara parsial) yang ditunjukan pada Tabel 8 dapat dianalisis sebagai berikut:

1. Pengaruh variabel Price Discount terhadap Purchase intention

Tabel 8 menunjukkan hasil uji thitung > tabel variable kualitas produk terhadap kepuasan konsumen yaitu sebesar $5.309>1.653$. Hal ini berarti bahwa hipotesis pertama dalam penelitian ini diterima.

2. Pengaruh variabel Bonus pack terhadap Purchase intention

Tabel 8 menunjukkan hasil uji thitung $>$ tabel variable kualitas produk terhadap kepuasan konsumen yaitu sebesar $2.565>1.653$. Hal ini berarti bahwa hipotesis kedua dalam penelitian ini diterima.

3. Pengaruh variabel Price Discount terhadap Purchase intention

Tabel 8 menunjukkan hasil uji thitung $>$ tabel variable kualitas produk terhadap kepuasan konsumen yaitu sebesar $16.716>1.653$. Hal ini berarti bahwa hipotesis ketiga dalam penelitian ini diterima.

Tabel 8. Hasil Uji t

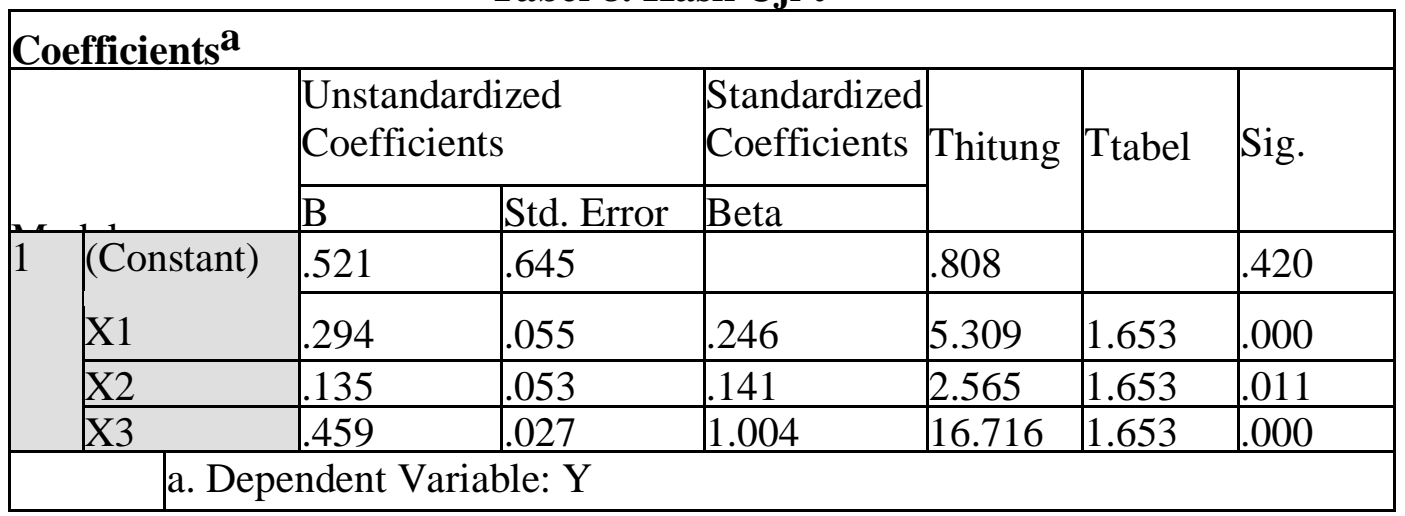

Sumber: Output SPSS 24 yang diolah, 2020

Dari tabel di atas dapat dilihat bahwa nilai signifikansi $\mathrm{F}$ yaitu 0,000 lebih kecil dari 0,050 dan Fhitung Lebih besar dari Ftabel, $136.263>2.66$, Hasil ini menunjukkan bahwa secara bersama-sama Price Discount (X1), Bonus pack (X2), dan Celebrity Endorser (X3) mempunyai pengaruh yang positif dan signifikan terhadap Purchase intention (Y). Maka berdasarkan hasil uji simultan maka Ho ditolak dan Ha diterima, antara variabel-variabel bebas yaitu Price Discount (X1), Bonus pack (X2), dan Celebrity Endorser (X3) mempunyai pengaruh yang signifikan secara bersama-sama terhadap Purchase intention (Y). 
Tabel 9. Hasil Uji F

\begin{tabular}{|c|c|c|c|c|c|c|c|}
\hline \multicolumn{8}{|c|}{ ANOVA $^{a}$} \\
\hline \multicolumn{2}{|c|}{ Model } & \begin{tabular}{|l} 
Sum of \\
Squares
\end{tabular} & Df & $\begin{array}{l}\text { Mean } \\
\text { Square }\end{array}$ & $F_{\text {hitung }}$ & $\mathrm{F}_{\text {tabel }}$ & Sig. \\
\hline \multirow[t]{3}{*}{1} & $\begin{array}{l}\text { Regressio } \\
n\end{array}$ & 599.816 & 3 & 199.939 & 136.263 & 3.66 & $.000^{\mathrm{b}}$ \\
\hline & Residual & 258.245 & 176 & 1.467 & & & \\
\hline & Total & 858.061 & 179 & & & & \\
\hline \multicolumn{8}{|c|}{ a. Dependent Variable: Y } \\
\hline \multicolumn{8}{|c|}{ b. Predictors: (Constant), X3, X1, X2 } \\
\hline
\end{tabular}

Sumber: Output SPSS 24 yang diolah, 2020

\section{Pembahasan}

\section{Pengaruh Price Discount Terhadap Purchase intention}

Dari hasil analisis yang telah dipaparkan diatas, dapat peneliti simpulkan bahwa variable Price Discount memiliki pengaruh yang positif dan signifikan terhadap Purchase intentions online shop Moy Stuff kota Bengkulu. Artinya bahwa hipotesis pertama yang diajukan dalam penelitian ini diterima. Sejalan dengan teori dan hasil penelitian yang telah dipaparkan sebelumnya dalam Bab 2 di atas, yang menyatakan bahwa variable Price Discount memiliki pengaruh positif terhadap Purchase intention. Price Discount juga termasuk dalam kegiatan promosi, di mana adanya Price Discount akan merangsang konsumen untuk melakukan pembelian langsung terhadap produk dalam waktu singkat, sehingga meningkatkan Purchase intention.

Berdasarkan penelitian terdahulu yang pernah dilakukan Gunawan et al. (2013) Hasil penelitian menunjukan bahwa variabel Price Discount berpengaruh terhadap Purchase intention pada infinite di surabaya.

\section{Pengaruh Bonus pack Terhadap Purchase intention}

Dari hasil analisis yang telah dipaparkan diatas, dapat peneliti simpulkan bahwa variable Bonus pack memiliki pengaruh yang positif dan signifikan terhadap Purchase intentions online shop Moy Stuff kota Bengkulu. Artinya bahwa hipotesis kedua yang diajukan dalam penelitian ini diterima. Sejalan dengan teori dan hasil penelitian yang telah dipaparkan sebelumnya, menyatakan bahwa variabel Bonus pack memiliki pengaruh positif terhadap Purchase intention. Finthariasari et al, (2020) menyatakan bahwa ketika jumlah tambahan atau ekstra item ditempatkan dalam paket produk khusus, itu adalah paket bonus. Adanya muatan ekstra dari sebuah produk dengan harga normal akan sangat mempengaruhi konsumen seketika didalam toko, mereka akan berfikir dua kali untuk tidak membeli. "beli satu dapat gratis satu" hanya dengan membeli satu produk konsumen bisa mendapat satu produk tambahan. Sejak isi produk ditambahkan dan tidak ada biaya extra, konsumen dapat dibujuk untuk membeli produk tersebut. Jika mereka merasa mendapatkan nilai yang lebih besar daripada uang yang mereka belanjakan.

\section{Pengaruh Celebrity Endorser Terhadap Purchase intention}

Dari hasil analisis yang telah dipaparkan diatas, dapat peneliti simpulkan bahwa variable Celebrity Endorser memiliki pengaruh yang positif dan signifikan terhadap Purchase intentions online shop Moy Stuff kota Bengkulu. Artinya bahwa hipotesis ketiga yang diajukan dalam penelitian ini diterima. Sejalan dengan teori dan hasil penelitian yang telah dipaparkan sebelumnya yang menyatakan bahwa variabel Celebrity Endorser memiliki 
pengaruh positif terhadap Purchase intention. Wang dan Tsai (2014) mengatakan bahwa sebuah perusahaan dapat bekerja untuk membangun kredibilitas merek didodorong oleh kualitas informasi yang disampaikan oleh perusahaan melalui strategi pemasaran yaitu dengan menggunkan Celebrity Endorser. Sehingga muncul minat beli dari konsumen untuk memperoleh produk tersebut karena sudah mendapatkan informasi dengan baik tentang merek perusahaan tersebut.

Berdasarkan penelitian terdahulu yang dilakukan Wijaya dan Sugiarto (2015) Hasil penelitian ini menunjukkan bahwa pengaruh selebriti pendukung Pond's yang memiliki keahlian, kepercayaan, daya tarik memukau dan kharisma yang kuat dalam mempengaruhi audience dapat membangun asosiasi merek yang positif. tersebut dapat diartikan bahwasanya Celebrity Endorser berpengaruh terhadap Purchase intention. Begitu juga dengan penelitian yang dilakukan Hansudoh (2012) Hipotesis dalam penelitian ini yang menyatakan bahwa Celebrity Endorsement berpengaruh terhadap Purchase intention pada produk Top Coffee di Surabaya diterima. Dengan demikian hipotesis dapat dibuktikan, nilai koefisien Inner weigh bertanda positif Mengindikasikan bahwa hubungan keduanya positif. Artinya semakin tinggi Celebrity Endorser, maka akan Semain tinggi pula tingkat Purchase intention Konsumen.

\section{Pengaruh Price Discount, Bonus pack, dan Celebrity Endorser Terhadap Purchase intention}

Jika dilihat dari hasil analisis perhitungan table uji $\mathrm{T}$ yang telah dipaparkan di atas, serta pembahasan hasil penelitian mengenai pengaruh antara variable independen (Price Discount, Bonus pack, dan Celebriity endorser) terhadap variable dependen (Purchase intention) secara parsial. Bahwa masing-masing variable independen (Price Discount, Bonus pack, dan Celebrity Endorser) memiliki pengaruh positif yang signifikan terhadap variable dependen (Purchase intention). Kemudian untuk hasil analisis uji $\mathrm{F}$ menyatakan bahwa secara simultan pun menunjukan bahwa variable independen (Price Discount, Bonus pack, dan Celebrity Endorser) memiliki pengaruh positif yang signifikan terhadap variable dependen (Purchase intention). Hubungan positif dan signifikan secara simultan antara tiga variabel independen dan dependen ini terjadi karena adanya hubungan positif yang disumbangkan dari masing-masing variabel independen terhadap variabel dependen.

\section{KESIMPULAN DAN SARAN}

Price Discount berpengaruh positif terhadap Purchase intention pada online shop Moy Stuff. Bonus pack berpengaruh positif terhadap Purchase intention pada online shop Moy Stuff. Celebrity Endorser berpengaruh positif terhadap Purchase intention pada online shop Moy Stuff. Berdasarkan uji koefisien determinasi $\left(\mathrm{R}^{2}\right)$ maka (X1), (X2), dan (X3) mempunyai pengaruh yang besar terhadap Purchase intention.

Peneliti berikutnya perlu meneliti lebih dalam tentang celebrity endorser secara luas pada beberapa kasus penjualan. Peneliti dapat pula menganalisis pengaruh factor lain yang berkaitan dengan celebrity endorser misal ketenaran dari celebrity endorser tersebut. Hal ini dapat dilakukan dengan beberapa tahap analisis validasi terlebih dahulu 


\section{DAFTAR RUJUKAN}

Annafik, A. F., dan Rahardjo, M. (2012). Analisis Pengaruh Kualitas Produk, Harga, dan Daya Tarik Iklan Terhadap Niat Membeli Sepeda Motor Yamaha (Studi Kasus Pada Konsumen Yamaha Ss Cabang Kedungmundu Semarang). Journal Of Management 1(2), 274-281.

Belch, G. E., dan Belch, A. A. (2009). Advertising and Promotion: An Integrated Marketing Communication Perspective, 8 th Edition. New York: Pearson Education. Boyd, H. W. (2002). Manajemen Pemasaran, Edisi Kedua. Erlangga, Jakarta.

Chen, H., Marmorstein, H., Tsiros, M., dan Rao, A. R. (2012). When More Is Less: The Impact of Base Value Neglect on Consumer Preferences for Bonus packs over Price Discounts. Journal of Marketing, 76 (4), 64-77.

Fintariasari, M., Ekowati, S., dan Feberiansyah, E. (2020). Pengaruh Promosi, Store Atmosphere, Dan Variasi Produk Terhadap Keputusan Pembelian. Jurnal Entepreneur dan Manajemen Sains, 1 (1).

Gunawan, A., Samuel, H., dan Dharmayanti, D. (2013). Analisis Pengaruh Store Name, Brand Name Dan Price Discounts Terhadap Purchase intention Konsumen Infnite Tunjungan Plaza.

Hansudoh, S.A. (2012). Pengaruh Celebrity Endorsement Terhadap Purchase intention Melalui Perceived Value Pada Produk Top Coffee di Surabaya. E-Journal Universitas Katolik Widya Mandala Surabaya, 1 (5), 1-7.

Kotler, P dan Keller, K. L. (2009). Manajemen Pemasaran. Jilid kedua Edisi ke-13, Alih Bahasa: Bob Sabran. Jakarta: Erlangga.

Machfoedz, M. (2005). Pengantar Pemasaran Modern, edisi pertama, cetakan pertama, Penerbit: UPP AMP YKPN, Yogyakarta.

Mishra, A., dan Mishra, H. (2011). The Influence of Price Discount Versus Bonus pack on the Preference for Virtue and Vice Foods. Journal of Marketing Research, 48 (1), 196-206.

Schiffman dan Kanuk. (2007). Perilaku Konsumen. Edisi Kedua. Jakarta: PT. Indeks Gramedia.

Shimp, A. T. (2003). Periklanan dan Promosi: Aspek Tambahan Komunikasi Pemasaran Terpadu. Alih bahasa oleh Revyani Syahrial dan Dyah Anikasari. Jilid 1. Jakarta: Penerbit Erlangga.

Suryadi, D. (2006). Promosi Efektif Menggugah Minat dan Loyalitas Pelanggan. Tugu Publisher: Yogyakarta.

Wang, Y, dan Tsai, C. (2014). The Relationship Between Brand Image and Purchase intention: Evidence From Award Winning Mutual Fund. The International Journal of Business and Finance Research, 8 (2), 27-40.

Wijaya, A. F., dan Sugiharto, S. (2015). Pengaruh Celebrity Endorsement Terhadap Purchase intention Dengan Brand Image Sebagai Variabel Intervening. Jurnal Manajemen Pemasaran. 9 (1), 16-22. 